\title{
Subsidy and fair competition
}

\begin{abstract}
Abbreviations: EAS, essential air service; PSO, Public Service Obligation; WTO, world trade organization; CAAC, civil aviation administration of china; ASEAN, association of southeast asian nations
\end{abstract}

\section{Introduction}

Government offering subsidy to airlines is not a novel idea in the aviation industry. In fact, the majority of flag carriers operating today are established with the help and support from the government. In 1978, the U.S. Congress passed the Deregulation Act to minimize government's interference within the U.S. domestic aviation market. The act aimed at removing the restrictions that the government has established within the air travel industry, which has favored flag carriers for decades. These restrictions included barriers of entry, fixed routing and predetermined airfares. Similar practices have been adopted in other parts of the world where other countries sought to deregulate their domestic aviation market.

The Convention on International Civil Aviation, also known as the Chicago Convention, was signed on 7 December 1944. It established the rules of airspace, aircraft registration and safety, and detailed the rights of the signatories in relation to air travel. It was signed by 52 signatory states and required the government of each nation to negotiate and agree upon a bilateral agreement to access the traffic rights based upon the freedom of the air.

The open-skies ${ }^{1}$ concept was pursued by the United States to liberalize the international air transport services with the aims of opening up the international aviation market to all non-government related agencies. This is based on the free market system. Under the free market concept in which the prices for goods and services are determined by the open market and consumers, in which the laws and forces of supply and demand are free from any intervention by a government, price-setting monopoly, or other authority. These, together with low-entry barriers, autonomy to set pricing strategies and establish routing systems have attracted many other airlines to enter the aviation market. As a result, consumers enjoy a greater choice of airlines to choose from and benefit from lower airfare.

\section{Type of subsidies}

The economic activities associated with aviation play an important role in a nation's income. It also increases international trade and stimulates developments in the tourism industry. Furthermore, exporting products and boosting tourism generates substantial additional income and job opportunities. Hence, governments began to offer different types of subsidies, both directly and indirectly to airlines so as to guarantee their productivity and to ensure continued economic growth.

\section{Essential air service}

The Essential Air Service (EAS) is a program implemented by the U.S. federal government to support small communities. Its aim is to maintain a minimal level of scheduled air service to these communities that otherwise would not be profitable. This came in response to the Airline Deregulation Act, ${ }^{2}$ passed in 1978, which gave U.S. airlines freedom to determine which markets to serve domestically and what fares to charge. This has created a very competitive air transportation industry as national airlines only operate routes which are considered
Volume I Issue 2 - 2017

Colin Law
Faculty of Hospitality and Tourism, Prince of Songkla University,
Thailand

Correspondence: Colin Law, Faculty of Hospitality and Tourism, Prince of Songkla University, Thailand, Tel +66-76276860,Email colinlaw2603@gmail.com

Received: June 27, 2017 | Published: July 14, 2017

profitable, leaving out some rural areas due to a lack of travel demand. To encourage airline operating services serving these unprofitable routes in the rural areas, the federal government has offered subsidies to cover the airlines' losses.

As of October 2016, the EAS program has supported 113 communities in 48 states by offering subsidies to the costs and expenses exceeding USD 200. ${ }^{1}$ In the context of European Union law, ${ }^{3}$ the public service obligation (PSO) is a subsidiary that the government offers to an airline to operate an air transportation service between cities that no other air carriers are interested and more often than not, the government pays subsidies to cover the airline's losses.

In China, the Civil Aviation Administration of China (CAAC) is subsidizing airlines that operate routes in some remote cities and rural areas of Xinjiang, Sichuan, Inner Mongolia, Yunnan and Guizhou. ${ }^{4}$ A similar program is also financed by the Indian government ${ }^{5}$ in which a regional connectivity scheme offers subsidies to airlines that operate some 128 routes over 45 unserved and underserved airports to provide air transportation between rural cities and urban areas.

\section{Subsidies for tourism industry}

Some governments provide subsidies to airlines that help to generate the nations' tourism industries. One example is Israel. It offers a subsidy of 45 Euros per passenger to airlines that operate direct flights to Ovda Airport, a military air base and civilian airport in the remote Uvda region of southern Israel. ${ }^{6}$

In addition, the Turkish government has increased a subsidy it pays to the operators of charter flights bringing foreign tourists into the country and into cities such as Antalya, Alanya, Dalaman, Bodrum and Izmir in an attempt to bolster visitor numbers which have fallen sharply due to a series of bomb attacks and tensions with Russia. The government has offered a 30 percent increase on the $\$ 6,000$ subsidy for charter flights carrying at least 150 passengers during the peak summer holiday season.?

As international airlines seldom offer services to second tier cities due to lack of travel demand, many airlines that operate services to the major cities provide domestic connecting flights to smaller municipalities through code sharing. This has encouraged some local administrations of second tier cities are offering subsidies to attract international airlines to commission direct services to these areas. In China, a number of provincial administrations are offering up to 2 million RMB of subsidies to airlines that operate direct international 
route to these rural cities. As of 2012 , there are a total 18 Chinese provinces offering subsidies to 63 airlines that operate a total of 107 international routes. ${ }^{8}$

\section{Subsidizing airport charges}

To promote flight movements, some airports are offering incentives to attract airlines to set up hub operations within their airports. In addition, most government owned airports offer reduced landing fees, aircraft parking fees and facility rental fees to airlines using these airport facilities. As an example, Ryanair, an Irish low-cost airline founded in 1984, with its primary operational bases at Dublin and London Stansted airports.

In 2016, Ryanair was the largest European airline by scheduled passengers flown, and carried more international passengers than any other airline. To attract Ryanair Airline, established routes to their cities, many European airports have offered Ryanair concessionaires to motivate the airline to offer flights from various destinations to these local airports. These concessionaires include waived landing fees and free check-in desks. ${ }^{9}$

\section{Fuel subsidies}

Many governments are supporting the aviation industry by offering fuel subsidies that exempt fuel tax for aircraft refuels. This is seen in the case of the Saudi Arabia government that has offered a fuel subsidy to the state owned Saudi Arabian airlines in return for low priced tickets that benefit the public. ${ }^{10}$ The government of North Carolina has offered a similar tax exemption on aviation fuel for commercial aircrafts in a bid to encourage frequency of flights. ${ }^{11}$

\section{Bailout subsidies}

Over the last decade, numerous airlines that had experienced financial difficulties were granted government-funded bailout programs. These governments offered loans, write-offs and tax breaks to support these airlines' restructure. In 2010, Japan Airlines, the flag carrier of Japan, received a 350billion-yen capital injection from a state-backed fund after it filed for bankruptcy. ${ }^{12}$ Several US carriers such as United Airlines (2003), Delta Airlines (2005) and American Airlines (2011) have also obtained bailout support from the government.

\section{The debate}

Over the last few years, there has been a debate over fair competition in the aviation industry. In 2014, Air France-KLM and the Lufthansa Group expressed their concerns to the European Commission of the Gulf carriers over stiff competition from airlines from the Arabian Gulf in the long-haul international market. ${ }^{13}$ Similar concerns were also raised by the US carriers about unfair competition over Gulf carriers receiving subsidies from the government. ${ }^{14}$

Airlines from the United Stated and Europe have complained that the stated-owned Gulf carriers obtained financial support from their respective governments and are using the government fund to expand rapidly their operations, purchase new aircrafts, offer relatively lower fare, advance on-board amenities and better service to draw customers away from US and European carriers.

These accusations were denied by Emirates, an airline based in Dubai, United Arab Emirates. The airline published an official report on airline subsidies and reconfirmed that it did not receive any subsidies or concessionaires from the Dubai government. Emirates also released a statement stating that it was no different from other airlines as it has a similar cost structure and pays the same amount of landing fees and airport rent, just like the other airlines. ${ }^{15}$ Qatar Airways and Etihad Airways were based in the Arabian Gulf also have denied these allegations. In response to these claims, these carriers claimed that these US airlines have also received financial aid from the US government and added that customers were drawn to these airlines because of the lower air fares and high quality of services provided, which are sorely lacking in US airlines. ${ }^{16}$

\section{The root of the problem}

Typically, consumers need to fly from the smaller cities to a hub before they connect to an international flight. Under open-skies agreements, foreign airlines can operate direct services to any cities from an international destination. Apart from bringing convenience to passengers, the increased competition has allowed passengers to enjoy a relatively low airfare, while giving them the option to choose from a wider variety of airlines at the same time. Traditionally, passengers who travel from Asia to the United States have to fly through the standard eastbound route via the Pacific Ocean, such as a flight from Vietnam bounded for New York with a transit in Tokyo. Today, air liberalization has allowed the Gulf carriers to offer similar services in other cities as passengers now have the option of flying westbound via the Middle East and Atlantic Ocean from Vietnam to the United States. At the same time, these Gulf airlines are able to attract potential customers from different continents with their newly established hubs in the Middle East.

This has proved to be problematic for European and US carriers that are beginning to suffer losses on these profitable eastbound and westbound routes that they once dominated. An increasing number of passengers from Asia are choosing flying west ward to the United States with Gulf carriers via the Middle East. To make matters worse, the eastern Pacific route is now swarmed by the numerous governmentsubsidized Chinese carriers that offered discounted airfares. ${ }^{17}$

The reasons of the U.S. carriers lodging complaints against the Gulf carriers, but not the Chinese airline is mainly due to flaws in the open-skies agreement. The liberalization between the United States and the Middle East has resulted in many new destinations in the former while there are only a few access points in the Middle East. This has created an imbalanced market between the two regions.

In comparison, the Chinese market is larger, with more areas accessible to tourism, hence creating more opportunities for the airlines to compete. A similar problem is seen found in the Asia Pacific region, which resulted in Indonesia's prior refusal to agree upon the ASEAN open-skies agreement as this resulted in the Indonesia archipelago creating many new destinations for smaller countries such as Singapore and Brunei had only one access point.

As of June 2017, Emirates is operating 75direct flights per week from Dubai to 12 different US cities and 14 flights with fifth freedom access from Doha to New York via Milan or Athens. Qatar Airways operates 77 flights a week from Doha to 10 US cities and Etihad Airways operates 38 weekly flights from Abu Dhabi to 5 US cities. Jumping on the bandwagon, United Airlines launched a daily flight from US to Doha via Dubai in 2012 mainly serving US officials travelling between the United States and the Middle East.

However, the service was canceled in 2015 when United Airlines lost the government contract to operate this route and it was instead, awarded the contract to Jet Blue, an American low-cost carrier and the sixth largest airline in the United States, and with actual flight route 
operated by their code share partner, Emirates. ${ }^{18}$ Delta Airlines start operating flights from Atlanta to Dubai from 2001 and the route was canceled in 2016 due to overcapacity. ${ }^{19}$ The ratio of weekly flights between Gulf Carrier and US carriers in the Middle East-US market as of June 2017 is 204:0.

At the same time, Chinese carriers currently operate more than 180 weekly flights to 10 US destinations whilst U.S. carriers charter more than 160 flights to 5 major cities in China. The ratio of weekly flights between Chinese carriers and US carriers in the Chinese-US market as of June 2017 is 160:180 (Table 1).

Table I Statistics as of June 2017

\section{Statistics as of june}

2017

\begin{tabular}{|c|c|c|}
\hline \multirow{2}{*}{$\begin{array}{l}\text { Ratio of carriers between } \\
\text { Middle East carrier and US } \\
\text { carriers over the Middle } \\
\text { East-US market }\end{array}$} & $\begin{array}{l}\text { Gulf carriers(EK, } \\
\text { QR, EY) }\end{array}$ & $\begin{array}{l}\text { US carriers(AA, } \\
\text { DL,UA, HA) }\end{array}$ \\
\hline & 204 & 0 \\
\hline \multirow{2}{*}{$\begin{array}{l}\text { Ratio of carriers between } \\
\text { Chinese Carrier and US } \\
\text { carriers over the China-US } \\
\text { market }\end{array}$} & $\begin{array}{l}\text { Chinese } \\
\text { carriers(CA, MU, } \\
\text { CZ,HU) }\end{array}$ & $\begin{array}{l}\text { US carriers(AA, } \\
\text { DL,UA, HA) }\end{array}$ \\
\hline & 180 & 160 \\
\hline
\end{tabular}

The aviation industry and academia in the United States are worried that this continual diminishing passenger load could lead to the US carriers reducing flight frequencies of international flight, and having a spillover effect on domestic services. Today, most flag carriers today operate on a hub-and-spoke network, which transfers passengers from international flight to domestic services. Reducing international flight frequencies hence greatly reduces passengers' demands for domestic flight services. This destabilizing of the airline industry in the US market is becoming a real cause of concerns and US airlines are at risk of running into yet another financial crisis.

Should governments refuse to support or bail out the airlines in difficulties, mergers and declarations of bankruptcy are then expected. The resulting loss of a local airline or domestic flight route would lead to a blow to the country's economy. The reduction in competition airline will also lead to an increase of airfares and unemployment rates (Table 2).

Table 2 Effects of liberalization

\section{Effects of liberalization}

\begin{tabular}{ll}
\hline Short-term effects & Long-term effects \\
\hline Passengers & \\
Cheaper airfare & Reduced airline choices \\
Better services & Increased airfare \\
$\begin{array}{l}\text { More airlines to choose from convenient service } \\
\text { Airline }\end{array}$ \\
$\begin{array}{l}\text { Intense competition } \\
\text { Competition over price and }\end{array}$ & Airline bankruptcy \\
service & Mergers \\
\end{tabular}

Table Continued

\section{Effects of liberalization}

Short-term effects Long-term effects

\section{Nations}

Economic growth

Increase in unemployment (due to airline mergers).

Tourism industry development

Over reliance on foreign carriers (due to flag carrier declaring bankruptcy).

Increase in employment

\section{What is fair and equal opportunity?}

The major concern over this debate is whether open-skies really operate as a free market within the aviation industry and whether the airlines are getting a fair and equal opportunity in the market, as mentioned in Article 11 of the US open-skies agreement. ${ }^{1}$

Air liberalization was initially established to create a free market environment in international air travel and introduce free competition and its benefits to the participating nations. However, the topic of subsidy was not addressed in the open-skies agreement. While the World Trade Organization (WTO) has implemented a set of rules on subsidies and a number of countervailing measures on import and export of commercial products, these rules do not apply to the airline industry. ${ }^{20}$

While the ideal scenario is that of a true open sky, the reality is that governments need to offer subsidies to airline in order to keep the air transport network operating. To create a fair and competitive market, the open skies agreement between nations should include directives on subsidies. By identifying the type of acceptable subsidies applicable to the airline industry, this will minimize conflicts among airlines due to unfair competition.

\section{Acknowledgments}

None.

\section{Conflict of interest}

Author doesn't have any conflict of interest.

\section{References}

1. US Department of State. Current Model Open Skies Agreement Text. US Department of State, USA; 2012. p. 1-15.

2. US Department of Transport. Essential Air Service. Aviation Policy. US Department of Transport. Washington, USA; 2017.

3. Mobility and Transport. European Commission. 2017.

4. Hu Y. The Civil Aviation Authority subsidized regional aviation over one billion RMB and Sichuan received second largest sum in the country in 2016. Huaxi City Daily. 2016.

5. Government of India. Govt awards 128 air routes under regional connectivity scheme. The Times of India. 2017.

6. Melnitcki G. Ryanair Launches 15 New Flight Routes Between Israel and Europe. Israel news, Harretz. 2017.

7. Ersen H, Sheahan M. Turkey to offer fuel subsidies for flights to bring back tourists. Reuters. 2016. 
8. Le T. British Airways to cancel Chengdu route. Global Times. 2016.

9. Byrne G. Ryanair profits boosted by subsidies, say rivals. The Irish Times. 2010.

10. State-Protected Airlines in Middle East: Part I. Transportation, OASEAST. 2015.

11. Form E-505. Sales and Use Tax Division. North Carolina Department of Revenue, US; 2016. p. 9-12.

12. JiJi. End of JAL bailout curbs expected to shake up airline industry. The Japan Times. 2017.

13. Flottau J, Unnikrishnan M. France, Germany Protest Gulf Carrier Encroachment. Aviation Week Network. 2015.

14. Liang K. US airlines blame Gulf carriers for international passenger dip. The Hill. 2016.
15. Emirates. Airlines and subsidy: our position. Emirates. 2012.

16. Reed D. The Emirates Strike Back: Persian Gulf Carriers Go On The Offensive VS U.S.' Big 3. Logistics \& Transportation, Forbes USA; 2015.

17. Whitley A, Park K. Chinese Airlines Are Flooding the World With Super-Cheap Airfares. Bloomberg. 2016.

18. Dastin J. United Airlines to stop flying to Dubai. Reuters. 2015.

19. Carter P. Setting record straight on canceling ATL-Dubai route. Delta Airlines. 2015.

20. Walulik J. Progressive Commercialization of Airline Governance Culture. Routledge, New York, USA; 2017. p. 278.

21. Zhang V. China's Allocation of Subsidies to Regional Flights Questioned: Report. China Aviation Daily. 2013. 